\title{
MicroRNAs May Serve as Emerging Molecular Biomarkers for Diagnosis and Prognostic Assessment or as Targets for Therapy in Gastric Cancer
}

\author{
Yong-Ping Mü ${ }^{1,2}$, Wen-Jie Sun ${ }^{2 *}$, Chuan-Wen Lư ${ }^{3}$, Xiu-Lan $\mathrm{Su}^{4}$
}

\begin{abstract}
Gastric cancer (GC) is one of the most common cancers, with high incidences in East Asia countries. Most GC patients have been reported with low early diagnosis rate and show extremely poor prognosis. Therefore, it is necessary to develop novel and more sensitive biomarkers to improve early diagnosis and therapy in order to provide longer survival and better quality of life for gastric cancer patients. MicroRNAs (miRNAs) play crucial roles in GC development and progression. miRNAs have emerged as a novel molecular biomarker for cancer diagnosis, prognosis and therapy with surprising stability in tissues, serum or other body fluids. This review summarizes major advances in our current knowledge about potential miRNA biomarkers for GC that have been reported in the past two years.
\end{abstract}

Keywords: MicroRNAs - gastric cancerv biomark

Asian Pac J Cancer Prev, 16 (12), 4813-4820

\section{Introduction}

Gastric cancer (GC) is one of the most common cancers. Despite a steady decrease of GC incidence and mortality during the last decade, GC still ranked second in global cancer mortality (Wu et al., 2006), especially in East Asia (Jemal et al., 2011). Although currently radical surgery and chemotherapy can be curative for early-stage GC, however, the five-year survival rate is only $20-30 \%$ (Crew and Neugut, 2006). Therefore, it is necessary to develop novel and more sensitive biomarkers to improve early diagnosis and therapy in order to provide longer survival and better quality of life for gastric cancer patients.

MicroRNAs (miRNAs) are a small class of nucleic acids (approximately 20-24 bases) that function in transcriptional and post-transcriptional regulation of gene expression (Lee et al., 2003). Since the first discovery of two miRNAs (lin-4 and let-7) in the 1990s, an increasing number of miRNAs have been successfully identified in various organisms. Currently the latest miRBase release (v20, June 2013), which contains 24521 microRNA loci from 206 species, is estimated to control more than $30 \%$ of all genes. The regulation of miRNAs expression plays important roles in pathogenesis of gastric cancer, such as proliferation, invasion, metastasis, apoptosis, and
Helicobacter pylori infection. Moreover, a number of miRNAs have been shown to be associated with tumor type, tumor stage, and patient survival. Furthermore, as miRNAs in tissue, FFPE, plasma/serum, urine, saliva and milk (Ma et al., 2013b) (Lasser, 2013) are well protected from RNases, they remain stable under harsh conditions including boiling, low/high $\mathrm{pH}$, extended storage time, and freeze-thaw cycles (Chen et al., 2008). Hence, the levels of miRNAs are stable, reproducible, and consistent among individuals of the same species even for several years (Keller et al., 2011) (Sun et al., 2012). Their stability and easily testable length (about $22 \mathrm{bp}$ ) make them well suited for being utilized as biomarker for the early detection and prognosis of GC. Therefore, aberrantly expressed miRNAs have received a great deal of attention as potential sensitive and accurate molecule biomarkers for GC diagnosis, prognosis, and therapeutic target. This review summarizes major advances in our current knowledge about potential miRNA biomarkers for gastric cancer that have been reported in the past two years.

\section{MicroRNAs's Function in Gastric Cancer}

Aberrant miRNA expression has been associated with oncogenesis. Some miRNAs act as tumor suppressors, whereas others as oncogenes, depending on their targets

\footnotetext{
${ }^{\prime}$ Department of Clinical Laboratory Center, The Affiliated People's Hospital of Inner Mongolia Medical University, Hohhot, Inner Mongolia Autonomous Region, China, ${ }^{2}$ School of Public Health and Tropical Medicine, Tulane University, New Orleans, Louisiana, ${ }^{3}$ Department of Environmental Toxicology, The Institute of Environmental and Human Health, Texas Tech University, Texas Tech University Health Sciences Center, Lubbock, Texas, USA, ${ }^{4}$ Clinical Medicine Research Center, The Affiliated Hospital of Inner Mongolia Medical University, Hohhot, Inner Mongolia Autonomous Region, China*For correspondence: xlsu@hotmail.com; ypmu040@sina.com
} 
(Ekimler and Sahin, 2014). It is known that miRNAs play pivotal roles in various biological processes, such as proliferation, invasion, metastasis, cell cycle, resistance to apoptosis, angiogenesis and Helicobacter pylori infection (Tian et al., 2014). An emerging understanding of miRNAs's function has provided insight into the novel biomarkers of GC (Hayes et al., 2014; Tufekci et al., 2014).

Evidences show that microRNAs are associated with gastric cancer proliferation, migration and invasion. For example, miR-125a-5p serves as a potential tumor suppressor gene in gastric carcinogenesis. The regulation of $\mathrm{miR}-125 \mathrm{a}-5 \mathrm{p}$ is associated with gastric cancer metastasis by targeting E2F3. Ectopic expression of miR$125 \mathrm{a}-5 \mathrm{p}$ substantially inhibits the proliferation, migration and invasion by targeting E2F3 in gastric cancer cells (Xu et al., 2014b). In addition, Liu et al identified that the expression of miR-126, which regulates tumor suppressor genes like, PLK2, was decreased in gastric cancer cells and tissues (Liu et al., 2014b). Another study identified that the expression of miR-449a was decreased in gastric carcinoma and the up-regulation of miR-449a expression resulted in the inhibition of MGC-803 cell proliferation (Li et al., 2014b). Furthermore, miR-124 can inhibit the growth and invasion of gastric cancer by targeting ROCK1 (Hu et al., 2014a). miR-410 can suppress the migration and invasion by targeting MDM2 in gastric cancer (Shen et al., 2014a). miR-129-1-3p can promote proliferation of BGC-823 cells by targeting PDCD2 (Du et al., 2014). miR-92 mimics significantly promoted, while its antisense oligos inhibited gastric cancer cell proliferation and invasion (Duan and Fang, 2014). miRNA-21 stimulates gastric cancer growth and invasion by inhibiting the tumor suppressor effects of programmed cell death protein 4, phosphatase, and tensin homolog (Li et al., 2014a). miR-520d-3p contributes to GC progression via the regulation of EphA2, which could serve as a novel prognostic and therapeutic marker (Li et al., 2014c). miR375 is negatively regulated by Snail gene and involved in gastric cancer cell migration and invasion potentially by targeting JAK2 (Xu et al., 2014c). Over-expression of miR-126 inhibits GC cells invasion by targeting Crk. miR-129-1-3p inhibits the BGC-823 cell migration by targeting BDKRB2 (Li et al., 2014d). Down-regulation of microRNA-155 accelerates cell growth and invasion by targeting c-myc in human gastric carcinoma cells (Sun et al., 2014). These findings indicate the importance of miRNA in gastric cancer.

Recent studies have revealed the important roles of miRNA in the regulation of angiogenesis. For example, miR-382 induced by hypoxia promotes angiogenesis and acts as an angiogenic oncogene by repressing PTEN (Seok et al., 2014). Another study (Zheng et al., 2013) showed that miR-145 suppresses Ets 1 expression via the binding site in the 3'-UTR, thus inhibiting the invasion, metastasis, and angiogenesis of gastric cancer cells.

Also, miRNA is involved in cell cycle arrest and apoptosis, for example, tumor suppressor miR-24 restrains gastric cancer progression by down-regulating RegIV. Ectopic expression of miR-24 in SGC-7901 GC cells suppressed cell proliferation, migration and invasion in vitro as well as tumorigenicity in vivo by inducing cell cycle arrest in G0/G1 phase and promoting cell apoptosis (Duan et al., 2014). Microarray analyses of AGS cells demonstrated that CDK2, BMI-1 and Girdin, which are targets of miR-1246, miR-302a and miR-4448, were suppressed by treatment with SAHA and DZNep, leading to cell cycle arrest, apoptosis, and reduced migration of AGS cells (Hibino et al., 2014). miR-30b, as a novel tumor suppressor gene, regulats the apoptosis of cancer cells by targeting PAI-1 (Zhu et al., 2014a). The overexpression of miR-421 promotes gastric cancer cell growth and inhibited apoptosis of BGC-823 gastric cancer cells (Wu et al., 2014). These findings suggest the possibility for miRNA as a therapeutic target in GC.

Helicobacter pylori (H. pylori) infection caused progressive damage to the stomach may eventually results in gastric atrophy and increases the risk of GC (El-Zimaity et al., 2002). miRNA have the potential to affect on the outcome of the bacteria-host interaction, which leads to the identification of miRNA in association with the inflammatory response initiated by the $H$.pylori infection. A study shown that miR-375 was down-regulated in response to $H$. pylori infection in gastric epithelial cells, demonstrating that the miR-375 regulated JAK2-STAT3 pathway is involved in $H$. pylori-induced inflammation by affecting the expression of BCL-2 and TWIST1 (Miao et al., 2014). The findings indicate a potential therapeutic target for inflammation-related cancers. Additionally, the decreased expression of miR-204 in H.pylori-associated GC promotes cancer cell proliferation and invasion by targeting SOX4. miR-204 may act as a tumor suppressor in H. pylori induced gastric cancer (Zhou et al., 2014). Kiga et al., finds that DNA methylation of the miR-210 gene increased in Hp-positive human gastric biopsies as compared with Hp-negative controls (Kiga et al., 2014). Their results highlight inflammation-induced epigenetic silencing of miR-210 as a mechanism of induction of chronic gastric diseases, including cancer, during $\mathrm{Hp}$ infection.

\section{MicroRNAs as Diagnostic Biomarkers}

miRNA expression profiles and next-generation sequencing have revealed that miRNA aberrant expression could be used for tissue specificity and classify cancer types, suggesting the potential of using miRNAs for cancer diagnosis. For example, the expression of miR106b 25 cluster in tumor tissues was correlated with tumor size, borrmann type, depth of tumor invasion (T), lymph node metastases (N), distant metastasis (M) and TNM stage (Zhang et al., 2014a). Higher expression of Lin28B is associated with poorer prognosis in GC. Multivariate analysis revealed that the expression level of Lin28B $(P<0.001)$, TNM stage $(P<0.001)$ as well as differentiation grade $(P<0.001)$ were the three potential independent prognostic factors in the study (Hazard ratio $(\mathrm{HR})=2.108$ and $P=0.017, \mathrm{HR}=1.994$ and $P=0.018$, $\mathrm{HR}=1.939$ and $P=0.046$, respectively) (Hu et al., 2014b). The receiver operating characteristics (ROC) curve analyses suggested a considerable diagnostic accuracy of miR-222 for GC, and yielded an AUC (the areas under the ROC curve) of 0.850 with $66.1 \%$ sensitivity and 88.3 
Table 1. MicroRNAs's Function in Gastric Cancer

\begin{tabular}{|c|c|c|c|c|c|}
\hline Sample & Method & $\begin{array}{l}\text { MicroRNA(up/ } \\
\text { down-regu- } \\
\text { lated) } \\
\end{array}$ & Target gene & $\begin{array}{l}\text { Function(clinical patho- } \\
\text { logical factors) }\end{array}$ & Ref \\
\hline GCTs/ANTT & qRT-PCR & $\begin{array}{l}\operatorname{miR}-125 \mathrm{a}- \\
5 \mathrm{p}[\text { down }]\end{array}$ & E2F3 & $\begin{array}{l}\text { Proliferation/ invasion/ } \\
\text { migration/metastasis }\end{array}$ & (Xu et al., 2014a) \\
\hline $\begin{array}{l}\text { GCTs and GCCLs/ } \\
\quad \text { (SGC-7901) }\end{array}$ & qRT-PCR & $\begin{array}{l}\operatorname{miR}- \\
126[\text { down }]\end{array}$ & $\begin{array}{l}\text { PI3KR2 and Crk, } \\
\text { and the tumor sup- } \\
\text { pressor PLK2. }\end{array}$ & $\begin{array}{l}\text { Proliferation/ invasion/ } \\
\text { migration/metastasis }\end{array}$ & (Liu et al., 2014) \\
\hline GCTs and GCCLs & qRT-PCR & $\begin{array}{c}\text { miR- } \\
124[\text { down }]\end{array}$ & $\begin{array}{l}\text { Rho-associated } \\
\text { protein kinase } \\
\text { (ROCK1) }\end{array}$ & $\begin{array}{l}\text { Inhibits growth and inva- } \\
\text { sion }\end{array}$ & (Hu et al., 2014) \\
\hline GCCLs & QRT-PCR & $\begin{array}{c}\text { miR- } \\
410[\text { down }]\end{array}$ & MDM2 & $\begin{array}{c}\text { Suppresses migration and } \\
\text { invasion }\end{array}$ & (Shen et al., 2014) \\
\hline $\begin{array}{l}\text { GCCLs/(BGC- } \\
823) \\
\end{array}$ & QRT-PCR & miR-129-1-3p & $\begin{array}{l}\text { programmed cell } \\
\text { death } 2(\mathrm{PDCD} 2)\end{array}$ & $\begin{array}{c}\text { Promote cell prolifera- } \\
\text { tion }\end{array}$ & (Du et al., 2014) \\
\hline GCTs & QRT-PCR & miR-92[up] & $\begin{array}{l}\text { farnesoid } X \text { recep- } \\
\quad \text { tor }(\mathrm{FXR})\end{array}$ & $\begin{array}{c}\text { Promotes gastric cancer } \\
\text { cell proliferation and } \\
\text { invasion }\end{array}$ & $\begin{array}{l}\text { (Duan and Fang, } \\
\text { 2014) }\end{array}$ \\
\hline GCTs and GCCLs & QRT-PCR & $\begin{array}{l}\operatorname{miR}-520 \mathrm{~d}-3 \mathrm{p} \\
\text { [up] }\end{array}$ & EphA2 & $\begin{array}{c}\text { Inhibits gastric cancer } \\
\text { cell proliferation, migra- } \\
\text { tion, and invasion }\end{array}$ & (Li et al., 2014b) \\
\hline GCCLs & QRT-PCR & $\begin{array}{c}\mathrm{miR}- \\
375[\text { down] }\end{array}$ & JAK2. & & (Xu et al., 2014b) \\
\hline GCTs and GCCLs & QRT-PCR & $\begin{array}{c}\operatorname{miR}-126 \\
\text { [down] }\end{array}$ & $\begin{array}{l}\text { Crk (v-crk sarcoma } \\
\text { virus CT10 onco- } \\
\text { gene homolog) }\end{array}$ & & (Li et al., 2014c) \\
\hline $\begin{array}{c}\text { GCTs and } \\
\text { GCCLs(BGC-823) }\end{array}$ & QRT-PCR & miR-129-1-3p & & Inhibits cell migration & (Du et al., 2014) \\
\hline GCTs and GCCLs & & $\begin{array}{c}\text { miR- } \\
155[\text { down] }\end{array}$ & c-myc & $\begin{array}{l}\text { Accelerates cell growth } \\
\text { and invasion }\end{array}$ & (Li et al., 2014a) \\
\hline $\begin{array}{c}\text { GCTs/ANTT/ } \\
\text { GCCLs(MGC803) }\end{array}$ & $\begin{array}{l}\text { Quantitative (q) } \\
\text { PCR }\end{array}$ & $\begin{array}{c}\text { miR-449a } \\
\text { down-regulated }\end{array}$ & CDK6 & Apoptosis & (Sun et al., 2014) \\
\hline GCCLs & Microarray & $\begin{array}{l}\mathrm{miR}-1246, \\
\mathrm{miR}-302 \mathrm{a} \text { and } \\
\mathrm{miR}-4448\end{array}$ & DYRK1A & & $\begin{array}{l}\text { (Hibino et al., } \\
\text { 2014) }\end{array}$ \\
\hline $\begin{array}{c}\text { GCTs / GCCLs/ } \\
\text { Nude mouse xeno- } \\
\text { graft model } \\
\end{array}$ & & $\begin{array}{l}\text { miR- } \\
\text { 30b[down] }\end{array}$ & $\begin{array}{c}\text { plasminogen ac- } \\
\text { tivator inhibitor-1 } \\
(\mathrm{PAI}-1)\end{array}$ & Apoptosis & (Zhu et al., 2014) \\
\hline \multirow[t]{2}{*}{ GCTs and GCCLs } & & miR-421[up] & Bax and Bcl-2 & Oncogenes & (Wu et al., 2014) \\
\hline & & $\operatorname{miR}-362$ & NF-kappaB & Apoptosis resistance & (Xia et al., 2014) \\
\hline GCCLs(MKN1) & Microarrays & miR-382 & $\begin{array}{c}\text { phosphatase and } \\
\text { tensin homolog } \\
\text { (PTEN) } \\
\end{array}$ & Angiogenesis & (Seok et al., 2014) \\
\hline GCTs and GCCLs & & miR-145 & $\begin{array}{l}\text { Ets1 (oncogene } \\
\text { homolog 1) }\end{array}$ & Angiogenesis & $\begin{array}{c}\text { (Zheng et al., } \\
\text { 2013) }\end{array}$ \\
\hline GCCLs & & $\operatorname{miR}-375$ & $\begin{array}{l}\text { by blocking JAK2- } \\
\text { STAT3 signaling }\end{array}$ & $\begin{array}{c}\text { Inhibits Helicobacter } \\
\text { pylori-induced gastric } \\
\text { carcinogenesis }\end{array}$ & (Miao et al., 2014) \\
\hline Hp-positive tissues & qRT-PCR & $\begin{array}{c}\operatorname{miR}-204 \\
\text { [down] }\end{array}$ & SOX4 & $\begin{array}{c}\text { Promotes cancer cell } \\
\text { proliferation and invasion }\end{array}$ & (Zhou et al., 2014) \\
\hline $\begin{array}{l}\text { Hp-positive human } \\
\text { gastric biopsies / } \\
\text { Hp-negative con- } \\
\text { trols. }\end{array}$ & $\begin{array}{l}\text { PCR /DNA } \\
\text { methylation }\end{array}$ & $\operatorname{miR}-210$ & $\begin{array}{l}\text { STMN1 and } \\
\text { DIMT1 }\end{array}$ & & (Kiga et al., 2014) \\
\hline
\end{tabular}

*GCTs:gastric cancer tissues; GCCLs:gastric cancer cell lines;ANTT:adjacent non-tumor tissues; LN: Lymph node 
$\%$ specificity in discriminating $\mathrm{GC}$ from healthy controls (Fu et al., 2014). Results from Zhu et al., suggested that miR-106a was similarly up-regulated in gastric cancer regardless of sample types although fragmentation existed inevitably in formalin-fixed, paraffin-embedded (FFPE) tissues. Their research indicated that FFPE samples can serve as an important research tool for miRNA field, and the early changes of miR-106a detected in such samples may have clinical application as a potential biomarker for the discovery and diagnosis of gastric cancer (Zhu et al., 2014b). Researches from Yang et al., indicated that the expression levels of miR-9, miR-433, miR-19b and miR370 were down-regulated in GC, which provides diagnosis of this disease (Yang et al., 2014b). Yan et al., identified fourteen GC related miRNAs, three of which (miR-211, let-7b, and miR-708) were for the first time reported to be associated with GC by system biological analysis, ROC analysis, and literature mining (Yan et al., 2014). Liu et al., (Liu et al., 2014a), found high levels of has-miR-105, $-213 *,-514 b$, and $-548 n$ in cancerous tissues, indicating the aberrant expression of miRNAs in GC. Studies from Han et al. (2014) (Han and Hur, 2014), indicated the loss of miR-29c expression is an early event in the initiation of gastric carcinogenesis. Studies from Guo et al., revealed the potential use of monitoring miRNAs expression as diagnostic biomarkers and regulating miRNAs expression in future treatment for GC (Guo et al., 2013). The expression of miR-21, -103, -106a, -221 and -222 in GC are significantly higher than those of normal controls. Conversely, the expression of miR-143 and -195 in cancer tissues are significantly lower than those of normal tissues. A multivariate analysis demonstrated that the expressions of miR-143 and -195 are associated with clinicopathological parameters, including depth of invasion and lymph node metastasis, suggesting new diagnostic biomarkers for future treatment of GC. Besides,

Table 2. MicroRNAs as Diagnostic Biiomarkers

\begin{tabular}{|c|c|c|c|c|}
\hline Sample & Method & $\begin{array}{l}\text { MicroRNA(up/down- } \\
\text { regulated) }\end{array}$ & $\begin{array}{l}\text { Clinical pathological factors } \\
\text { Clinical application }\end{array}$ & References \\
\hline $\begin{array}{l}\text { GCTs and GC } \\
\text { plasma }\end{array}$ & QRT-PCR & $\begin{array}{c}\text { miR-106b-25 } \\
\text { cluster(miR-106, miR-93, } \\
\text { miR-25)[up] }\end{array}$ & $\begin{array}{l}\text { TNM diagnosis and predic- } \\
\text { tive prognosis }\end{array}$ & (Zhang et al., 2014) \\
\hline GCTs & & Lin28B[up] & Prognosis & (Hu et al., 2014b) \\
\hline in plasma & QRT-PCR & miR-222 & $\begin{array}{l}\text { Lymph node metastasis, } \\
\text { TNM stage, serosal invasion }\end{array}$ & (Fu et al., 2014) \\
\hline $\begin{array}{l}\text { FFPE and fresh } \\
\text { frozen tissues }\end{array}$ & $\begin{array}{l}\text { in situ hybridiza- } \\
\text { tion }\end{array}$ & miR-106a [up] & & (Zhu et al., 2014b) \\
\hline \multirow[t]{2}{*}{$\begin{array}{l}\text { GCTs/normal gastric } \\
\text { mucosa }\end{array}$} & QRT-PCR & $\begin{array}{l}\operatorname{miR}-9, \operatorname{miR}-433, \operatorname{miR}-19 b \\
\text { and miR-370 [down] }\end{array}$ & $\begin{array}{l}\text { Changes in their expres- } \\
\text { sion provide a basis for the } \\
\text { diagnosis }\end{array}$ & (Yang et al., 2014) \\
\hline & $\begin{array}{l}\text { systematic integra- } \\
\text { tive bioinformatics } \\
\text { framework }\end{array}$ & $\begin{array}{l}\text { miR-211, let-7b, and } \\
\text { miR-708 }\end{array}$ & Diagnostic biomarkers & (Yan et al., 2014) \\
\hline GCTs & $\begin{array}{l}\text { miRCURY array } \\
\text { LNA miRNA chip } \\
\text {;QRT-PCR }\end{array}$ & $\begin{array}{l}\text { has-miR-105, }-213 * \\
-514 \mathrm{~b} \text {, and }-548 \mathrm{~N}[\mathrm{up}]\end{array}$ & $\begin{array}{l}\text { Identification of aberrantly } \\
\text { expressed miRNAs in gas- } \\
\text { tric cancer. }\end{array}$ & (Zhu et al., 2014b) \\
\hline GCTs and GCCLs & $\begin{array}{l}\text { next generation } \\
\text { sequencing(NGS) } \\
\text { and Q RT-PCR }\end{array}$ & ITGB1 -miR-29c & $\begin{array}{l}\text { Diagnostic and therapeutic } \\
\text { biomarker }\end{array}$ & (Han and Hur, 2014) \\
\hline FFPE & Q RT-PCR & $\begin{array}{l}\text { miR-21, }-103,-106 a,-221 \\
\text { and }-222 \text { [up]miR-143 and } \\
-195 \text { [down] }\end{array}$ & $\begin{array}{c}\text { Treatment or as a diagnostic } \\
\text { biomarker. }\end{array}$ & (Guo et al., 2013) \\
\hline GCTs and GCCLs & & miR-18a & $\begin{array}{l}\text { Circulating miRNA could } \\
\text { be a useful biomarker for } \\
\text { screening GC and monitor- } \\
\text { ing tumor dynamics. }\end{array}$ & $\begin{array}{l}\text { (Tsujiura et al., } \\
\text { 2014) }\end{array}$ \\
\hline \multirow[t]{2}{*}{ GC plasma } & miRNA microarray & $\begin{array}{c}\operatorname{miR}-122 \text { [down] and miR- } \\
192 \text { [up] }\end{array}$ & $\begin{array}{c}\text { Biomarker for distant metas- } \\
\text { tasis }(\mathrm{GC} / \mathrm{DM}) \text { and gastric } \\
\text { cancer with no distant } \\
\text { metastasis }(\mathrm{GC} / \mathrm{NDM})\end{array}$ & (Chen et al., 2014) \\
\hline & $\begin{array}{l}\text { miRNA microarray } \\
\text { and QRT-PCR }\end{array}$ & $\begin{array}{c}\text { hsa-miR-196 [up] and hsa- } \\
\text { miR-148a [down] }\end{array}$ & & (Zheng et al., 2014) \\
\hline GCCLs & & $\operatorname{miR}-135 \mathrm{a}$ & $\begin{array}{l}\text { Therapeutic and prognostic } \\
\text { targets for EGC. }\end{array}$ & (Shin et al., 2014) \\
\hline
\end{tabular}

GCTs:gastric cancer tissues;GCCLs: gastric cancer cell lines; FFPE:formalin-fixed, paraffin-embedded; TNM:depth of tumor invasion (T); lymph node metastases $(\mathrm{N})$; distant metastasis (M) 
circulation is important for detecting and monitoring GC. For example, miR-18a in plasma is significantly higher in GC patients than healthy controls. The plasma miR-18a levels are significantly lower in postoperative patients as compared to preoperative patients. Therefore, the circulating of miR-18a could be a useful for GC screening and monitoring (Tsujiura et al., 2014). Additionally, Chen et al. (2014b) reported potential novel biomarkers of plasma miR-122 and miR-192 for the early detection of distant metastasis (DM) of GC. High plasma level of miR-122 in GC indicates a favorable prognosis for GC with DM. Furthermore, hsa-miR-196a and hsa-miR-148a have the potential to serve as candidate biomarkers for early gastric cancer (EGC) (Zheng et al., 2014). Shin et al., confirm the tumor-suppressive role of miRNA-135a, and demonstrate its role in lymph node $(\mathrm{LN})$ metastasis

Table 3. MicroRNAs as Prognostic Biomarkers

\begin{tabular}{|c|c|c|c|c|c|c|c|}
\hline \multirow{2}{*}{$\frac{\text { Sample }}{\text { GC plasma }}$} & Method (normalization) & \multicolumn{2}{|c|}{ MicroRNA(up/down-regulated) } & \multicolumn{3}{|c|}{ Clinical application } & \multirow[t]{2}{*}{ References } \\
\hline & qRT-PCR & \multicolumn{2}{|l|}{$\operatorname{miR}-222$} & \multicolumn{3}{|c|}{ Prognosis } & \\
\hline GCTs/ANT & qRT-PCR & \multicolumn{2}{|c|}{ miR-193b[down] miR-196a[up] } & \multicolumn{3}{|c|}{ Prognosis } & (Mu et al., 2014) \\
\hline GCTs & qRT-PCR & \multicolumn{2}{|l|}{ miR-215/192[up] } & \multicolumn{3}{|c|}{ Prognosis. } & (Xu and Fan, 2014) \\
\hline GC plasmas & qRT-PCR & \multicolumn{2}{|l|}{$\operatorname{miR}-21[\mathrm{up}]$} & \multicolumn{3}{|c|}{$\begin{array}{l}\text { Post-operative plasmas were an } \\
\text { independent prognostic factor }\end{array}$} & (Komatsu et al., 2013) \\
\hline GCTs & qRT-PCR & \multicolumn{2}{|l|}{ miR-185 [down] } & \multicolumn{3}{|c|}{$\begin{array}{l}\text { Prognostic factor associated } \\
\text { with clinical stage and } \\
\text { lymph node metastases. }\end{array}$} & (Tan et al., 2014) \\
\hline \multirow{2}{*}{\multicolumn{2}{|c|}{$\begin{array}{l}\text { GCTs/ANTT } \\
\text { GCTs/ANTT }\end{array}$}} & \multirow{2}{*}{\multicolumn{2}{|c|}{$\begin{array}{l}\operatorname{miR}-22[\text { down }] \\
\text { miR-206[down] }\end{array}$}} & \multirow{2}{*}{\multicolumn{3}{|c|}{ Prognostic marker }} & (Wang et al., 2013) \\
\hline & & & & & & & (Yang et al., 2013) \\
\hline \multicolumn{8}{|c|}{ GCTs:gastric cancer tissues; GCCLs: gastric cancer cell lines; ANTT:adjacent non-tumor tissues } \\
\hline \multicolumn{8}{|c|}{ Table 4. Polymophism of MicroRNAs as Prognostic Biomarkers } \\
\hline & \multicolumn{6}{|c|}{ (Population) } & References \\
\hline Japanese & $63 / 67$ & rs3746444 & $\operatorname{miR}-49$ & & $\mathrm{~A} / \mathrm{G}$ & $0.33(0.18-0.75)$ & (Tahara et al., 2013) \\
\hline Chinese & $\begin{array}{l}\text { 579GC/ 649atrophic gastritis } \\
\text { (AG)/721 control PCR-RFLP. }\end{array}$ & rs629367 CC & miR-let- & & $\mathrm{A} / \mathrm{C}$ & $\begin{array}{c}1.83(\log \text {-rank } \mathrm{P}=0.004) \\
\text { poor prognosis }\end{array}$ & (Xu et al., 2014a) \\
\hline Asians & gastrointestinal cancer & rs 2292832 & miR-14 & & $\mathrm{T} / \mathrm{C}$ & $1.15(1.03-1.30)$ & (Li et al., 2013) \\
\hline Chinese & PCR-RFLP & rs2910164 rs895819 & miR-146a mi & $-27 a$ & $\mathrm{G} / \mathrm{C}$ & $1.42(1.03-1.97)$ & (Song et al., 2013) \\
\hline Chinese & case-control population study & rs11671784 & miR-27 & & $\mathrm{G} / \mathrm{A}$ & & (Yang et al., 2014b) \\
\hline Chinese & 240/240 Taqman-PCR & rs928508 & pre-miR-? & & $\mathrm{A} / \mathrm{G}$ & $1.83(1.07-3.05)$ & (Mu and $\mathrm{Su}, 2012$ ) \\
\hline
\end{tabular}

*PCR-RFLP:polymerase chain reaction-restriction fragment length polymorphist

Table 5. microRNAs as Therapeutic Target

\begin{tabular}{|c|c|c|c|c|c|}
\hline Sample & Method & Targed & MicroRNA & $\begin{array}{l}\text { Clinical applica- } \\
\text { tion }\end{array}$ & Ref \\
\hline GCCLs & tumor xenografts & SOX4 and CDK6 & $\operatorname{miR}-129$ & $\begin{array}{l}\text { therapeutic target } \\
\text { and biomarker }\end{array}$ & $\begin{array}{l}\text { (Fesler et al., } \\
\text { 2014) }\end{array}$ \\
\hline $\begin{array}{l}\text { Serum samples and } \\
\text { GCCLs(SGC7901) }\end{array}$ & $\begin{array}{l}\text { RT-PCR and } \\
\text { miRNA microarray } \\
\text { chips }\end{array}$ & & $\operatorname{miR}-218$ & $\begin{array}{l}\text { reverse the multi- } \\
\text { drug resistance of } \\
\text { gastric cell line }\end{array}$ & $\begin{array}{l}\text { (Zhang et al., } \\
\text { 2014b) }\end{array}$ \\
\hline GCCLs & $\begin{array}{l}\text { qRT-PCR /situ } \\
\text { hybridization / im- } \\
\text { munohistochem- } \\
\text { istry }\end{array}$ & radixin & $\begin{array}{l}\text { miR-196a and } \\
\text {-miR-196b }\end{array}$ & $\begin{array}{l}\text { therapeutic poten- } \\
\text { tial in suppressing } \\
\text { GC metastasis }\end{array}$ & (Tsai et al., 2014) \\
\hline GCTs and GCCLs & RT- PCR & IGF1R and BCL2 & miR-503 & & (Wang et al., 2014) \\
\hline GCTs and GCCLs & RT-PCR & $\begin{array}{l}\text { IGF1R, IRS1, } \\
\text { mTOR, and BCL2. }\end{array}$ & $\operatorname{miR}-1271$ & & $\begin{array}{l}\text { (Yang et al., } \\
\text { 2014b) }\end{array}$ \\
\hline \multirow[t]{2}{*}{ FFPE } & $\begin{array}{l}\text { miRNA oligo } \\
\text { chips }\end{array}$ & & $\begin{array}{l}\text { miR-92b, } \\
\text { miR422a, miR- } \\
\text { 4732-5p and miR- } \\
4758-3 p\end{array}$ & $\begin{array}{l}\text { increase the } \\
\text { clinical efficacy } \\
\text { of DNA damage- } \\
\text { inducing chemo- } \\
\text { therapeutic drug } \\
\end{array}$ & $\begin{array}{l}\text { (Omura et al., } \\
\text { 2014) }\end{array}$ \\
\hline & & HDAC1 & miR-520h & chemotherapy & $\begin{array}{l}\text { (Shen et al., } \\
\text { 2014b) }\end{array}$ \\
\hline $\begin{array}{l}\text { GCTs and GCCLs } \\
\text { (SGC7901 and } \\
\text { SGC7901/DDP) }\end{array}$ & & RhoE & miR-200c & chemotherapy & $\begin{array}{l}\text { (Chang et al., } \\
\text { 2014) }\end{array}$ \\
\hline
\end{tabular}

microRNAs as therapeutic target 
in early gastric cancer. miRNA-135a and its target gene ROCK1 may be novel therapeutic and prognostic targets for EGC (Shin et al., 2014).

\section{MicroRNAs as Prognostic Biomarkers}

Various miRNAs have been proven to be associated with the clinical outcome of cancer. For example, unique miRNAs are associated with the prognosis of gastric cancer. Our recently study demonstrated that a strong correlation between the overall survival of patients and the expression of miR-193b and miR-196a (Mu et al., 2014). Also, miR-222 level is correlated with disease-free survival and overall survival and miR-222 is identified as an independent prognostic marker (Zhang et al., 2014a). Scirrhous type GC is highly metastatic with rapid disease progression and poor prognosis. Besides, MicroRNA-145 is a potential prognostic factor of scirrhous type gastric cancer (Naito et al., 2014). Moreover, miR-215/192 participates in gastric cancer progression. The upregulation of miR-215 or -192 has been reported to be associated with lymph node metastasis ( $\mathrm{Xu}$ and Fan, 2014). Postoperative plasma miR-21 expression could be a novel potential biomarker for GC prognosis and evaluation of surgery outcomes, especially in patients without a family history (Ma et al., 2013a). Researches from Tan et al., demonstrated that miR-185 could suppress tumor metastasis in gastric cancer, suggesting an independent prognosis factor (Tan et al., 2014). Furthermore, integrated miRNA network analyses identified a poor-prognosis subtype of gastric cancer, which characterized by the miR-200 family. Song et al., have uncovered a key miRNA regulatory network that defines the mesenchymal gastric cancer subtype significantly associated with poor overall survival in gastric cancer. Three of the miRNAs (miR200c, miR-200b, and miR-125b) targeting the most genes in the network are associated with survival. Functional experiments demonstrated that miR-200b could suppress ZEB1 and augment E-cadherin, which results in cell migration inhibition and tumor suppression in a mouse model (Song et al., 2014). In addition, studies from Wang et al., (Wang et al., 2013) provided the evidence that the reduced expression of miR-22 is associated with malignant development of GC indicating the potential use of miR22 in cancer therapy. Moreover, the down-regulation of microRNA-206 expression is a potent prognostic marker for patients with GC (Yang et al., 2013). Likewise, the plasma level of circulating miR-21 could be a reliable prognostic marker for the patients with GC (Komatsu et al., 2013). A meta-analysis showed that over-expression of miR-21 is associated with worse tumor differentiation, lymph node metastasis, and TNM stage, suggesting a prognostic value of miR-21 in patients with gastric cancer (Wang et al., 2014b). All the studies indicate the potential use of these small molecules miRNAs in predicting prognosis in gastric cancer after surgery.

\section{Polymophism of MicroRNAs as Prognostic Biomarkers}

Single-nucleotide polymorphisms (SNPs) in miRNA genes are a novel class of genetic variations in the human genome that are currently being identified and investigated in human cancers. Common SNPs in pre-miRNAs can be useful in the prognoses of gastric cancer. For example, the rs3746444 A allele carrier in the hsa-mir-499 is associated with better prognosis in advanced GC performing chemotherapy (Tahara et al., 2014). Beside, a new polymorphism biomarker rs629367 is associated with increased risk and poor survival of Chinese GC patients (Xu et al., 2014a). Moreover, two miRNA variants (miR499, miR-149) are associated with gastrointestinal cancer (GI) (Li et al., 2013). A marginally elevated GI cancer risk was discovered in the recessive model for miR-149 (TT $v s$. TC+CC: $\mathrm{OR}=1.15,95 \% \mathrm{CI}=1.03-1.30, P(\mathrm{~h})=0.68$, $P=0.02)$. Stratifying the results by ethnicity revealed a slight association between the recessive model and the Asian population (TT vs. TC+CC: $\mathrm{OR}=1.14,95 \% \mathrm{CI}$ : 1.01-1.29, $P(\mathrm{~h})=0.79, P=0.03)$. miR-149 may confer increased risk of susceptibility to gastrointestinal cancer, especially for Asians. A Chinese population study showed that genetic polymorphisms of miR-146a and miR-27a might contribute to the evolution of $H$.pylori-associated gastric lesions in this high-risk population (Song et al., 2013). Results from Yang et al., indicated that the G/A polymorphism in miR-27a gene (rs11671784) reduced miR-27a expression, leading to a reduced gastric cancer risk (Yang et al., 2014c). In addition, our recent finding suggested that polymorphism rs 928508 in pre-miR-30c increasing risk of gastric cancer is associated with AA genotype compared with GG genotype in a Chinese population (adjusted $\mathrm{OR}=1.83$, 95\%CI: 1.07-3.15 , $P=0.029)(\mathrm{Mu}$ and $\mathrm{Su}, 2012)$.

\section{MicroRNAs -Based Therapeutic Approaches}

miRNA-based cancer diagnostics and prognostics started to be used in clinical applications in order to improve current cancer treatment plans. miRNA-based therapeutics have been tested in both preclinical and clinical settings, and accumulating evidence suggests the therapeutic and diagnostic/prognostic potential use of miRNA. For example, miR-129 has been used as a novel therapeutic target and biomarker in gastrointestinal cancer (Fesler et al., 2014). In addition, drug resistancerelated miRNAs may be used to optimize the therapeutic strategies for cancer patients. The over-expression of miR-362 is reported to induce cell proliferation, colony formation, and resistance to cisplatin-induced apoptosis in BGC-823 and SGC-7901 gastric cancer cells (Xia et al., 2014). Moreover, miR-218 expression was upregulated more than 8 fold in gastric cancer after cytoreductive surgery and hyperthermic intraperitoneal chemotherapy, which results in an increased chemosensitivity to cisplatin. The expression of miR-218 has been demonstrated to increase gastric cancer cell chemosensitivity to cisplatin in vitro and inhibit gastric cell tumor growth in nude mice in vivo. The results suggested a new strategy for the treatment of GC by reducing multi-drug resistance through targeting miR-218 (Zhang et al., 2014b). Moreover, Overexpression of miR-196a/-196b enhances GC cell migration and invasion. Further, radixin was identified as a 
target gene of miR-196a/-196b. Elevated miR-196a/-196b expression in GC cells led to reduced radixin protein levels and vice versa. Taken together, miR-196a/-196b inhibitory oligonucleotides or overexpression of the radixin may thus have therapeutic potential in suppressing GC metastasis. miR-503 regulates cisplatin resistance of human gastric cancer cell lines by targeting IGF1R and BCL2. An in vitro drug sensitivity assay showed that over-expression of miR503 sensitized SGC7901/DDP cells to cisplatin (Wang et al., 2014a). miR-1271 regulates cisplatin resistance of human gastric cancer cell lines by targeting IGF1R, IRS1, mTOR, and BCL2 (Yang et al., 2014a). Studies from Omura et al., indicated that miR-92b, miR422a, miR4732-5p and miR-4758-3p are closely associated with relapse following $\mathrm{S}-1$ adjuvant chemotherapy in gastric cancer (Omura et al., 2014). On the other hand, studies from Shen et al., found that doxorubicin down-regulates HDAC 1 protein expression, by inducing the expression of HDAC1-targeting miR-520h, providing a new strategy to increase the clinical efficacy of DNA damage-inducing chemotherapeutic drugs by reducing the drug resistance (Shen et al., 2014b). Results from Chang et al., 2014 suggested that miRNA-200c can regulate the sensitivity of chemotherapy by cisplatin in GC through targeting RhoE (Chang et al., 2014). In addition, miR-1207-5p and miR-1266 are significantly decreased in GC tissues, and their ectopic expression inhibits gastric tumor growth in vitro and in vivo by suppressing hTERT. Delivery of these two miRNAs represents a novel therapeutic strategy for GC treatment (Chen et al., 2014a).

\section{Future Perspectives and Conclusions}

MicroRNAs are small noncoding RNAs that have emerged as important translational gene regulators in cancer cells. Although the development of miRNA biomarkers is still in its early stages, these small molecules possess enormous potential in future applications including early detection, prognosis, prediction of disease recurrence, monitoring of therapeutic response, and patient selection for therapy in gastrointestinal cancers. miRNA biomarkers will be used to improve the long-term survival and mitigate disease burden for GC patients.

\section{Acknowledgements}

This study was financially supported by Nature Science Foudation of Inner Mongolia Autonomous Region of China Grant No. 2015MS0825 and National Natural Science Foundation of China Grant No. 81160254.

\section{References}

Chang L, Guo F, Wang Y, et al (2014). MicroRNA-200c regulates the sensitivity of chemotherapy of gastric cancer SGC7901/DDP cells by directly targeting RhoE. Pathol Oncol Res, 20, 93-8.

Chen L, Lu MH, Zhang D, et al (2014a). miR-1207-5p and miR1266 suppress gastric cancer growth and invasion by targeting telomerase reverse transcriptase. Cell Death Dis, 5, 1034.

Chen Q, Ge X, Zhang Y, et al (2014b). Plasma miR-122 and miR-192 as potential novel biomarkers for the early detection of distant metastasis of gastric cancer. Oncol Rep, 31, 1863-70.
Chen X, Ba Y, Ma L, et al (2008). Characterization of microRNAs in serum: a novel class of biomarkers for diagnosis of cancer and other diseases. Cell Res, 18, 997-1006.

Crew KD, Neugut AI (2006). Epidemiology of gastric cancer. World $J$ Gastroenterol, 12, 354-62.

Du Y, Wang D, Luo L, et al (2014). miR-129-1-3p Promote BGC-823 Cell Proliferation by Targeting PDCD2. Anat Rec (Hoboken), 297, 2273-9.

Duan JH, Fang L (2014). MicroRNA-92 promotes gastric cancer cell proliferation and invasion through targeting FXR. Tumour Biol, 35, 11013-9.

Duan Y, Hu L, Liu B, et al (2014). Tumor suppressor miR-24 restrains gastric cancer progression by downregulating RegIV. Mol Cancer, 13, 127.

Ekimler S, Sahin K (2014). Computational Methods for MicroRNA Target Prediction. Genes (Basel), 5, 671-83.

El-Zimaity HM, Ota H, Graham DY, et al (2002). Patterns of gastric atrophy in intestinal type gastric carcinoma. Cancer, 94, 1428-36.

Fesler A, Zhai H, Ju J (2014). miR-129 as a novel therapeutic target and biomarker in gastrointestinal cancer. Onco Targets Ther, 7, 1481-5

Fu Z, Qian F, Yang X, et al (2014). Circulating miR-222 in plasma and its potential diagnostic and prognostic value in gastric cancer. Med Oncol, 31, 164.

Guo B, Li J, Liu L, et al (2013). Dysregulation of miRNAs and their potential as biomarkers for the diagnosis of gastric cancer. Biomed Rep, 1, 907-12.

Han TS, Hur K (2015). MicroRNA-29c mediates initiation of gastric carcinogenesis by directly targeting ITGB1.Gut, 64, 203-14.

Hayes J, Peruzzi PP, Lawler S (2014). MicroRNAs in cancer: biomarkers, functions and therapy. Trends Mol Med, 20, 460-9.

Hibino S, Saito Y, Muramatsu T, et al (2014). Inhibitors of enhancer of zeste homolog 2 (EZH2) activate tumor-suppressor microRNAs in human cancer cells. Oncogenesis, 3, 104.

Hu CB, Li QL, Hu JF, et al (2014a). miR-124 Inhibits Growth and Invasion of Gastric Cancer by Targeting ROCK1. Asian Pac J Cancer Prev, 15, 6543-6.

Hu Q, Peng J, Liu W, et al (2014b). Lin28B is a novel prognostic marker in gastric adenocarcinoma. Int J Clin Exp Pathol, 7, 5083-92.

Jemal A, Bray F, Center MM, et al (2011). Global cancer statistics. CA Cancer J Clin, 61, 69-90.

Keller A, Leidinger P, Gislefoss R, et al (2011). Stable serum miRNA profiles as potential tool for non-invasive lung cancer diagnosis. RNA Biol, 8, 506-16.

Kiga K, Mimuro H, Suzuki M, et al (2014). Epigenetic silencing of miR-210 increases the proliferation of gastric epithelium during chronic Helicobacter pylori infection. Nat Commun, 5, 4497.

Komatsu S, Ichikawa D, Tsujiura M, et al (2013). Prognostic impact of circulating miR-21 in the plasma of patients with gastric carcinoma. Anticancer Res, 33, 271-6.

Lasser C (2013). Identification and analysis of circulating exosomal microRNA in human body fluids. Methods Mol Biol, 1024, 109-28.

Lee Y, Ahn C, Han J, et al (2003). The nuclear RNase III Drosha initiates microRNA processing. Nature, $\mathbf{4 2 5}, 415-9$.

Li L, Sheng Y, Lv L, et al (2013). The association between two microRNA variants (miR-499, miR-149) and gastrointestinal cancer risk: a meta-analysis. PLoS One, $\mathbf{8}, 81967$.

Li L, Zhou L, Li Y, et al (2014a). MicroRNA-21 stimulates gastric cancer growth and invasion by inhibiting the tumor suppressor effects of programmed cell death protein 4 and phosphatase and tensin homolog. J buon, 19, 228-36.

Li LP, Wu WJ, Sun DY, et al (2014b). miR-449a and CDK6 in gastric carcinoma. Oncol Lett, 8, 1533-8.

Li R, Yuan W, Mei W, et al (2014c). MicroRNA 520d-3p inhibits gastric cancer cell proliferation, migration, and invasion by downregulating EphA2 expression. Mol Cell Biochem, 396, 295-305.

Li X, Wang F, Qi Y (2014d). MiR-126 inhibits the invasion of gastric cancer cell in part by targeting Crk. Eur Rev Med Pharmacol 


\section{Sci, 18, 2031-7.}

Liu D, Hu X, Zhou H, et al (2014a). Identification of Aberrantly Expressed miRNAs in Gastric Cancer. Gastroenterol Res Pract, 2014, 473817 .

Liu LY, Wang W, Zhao LY, et al (2014b). Mir-126 inhibits growth of SGC-7901 cells by synergistically targeting the oncogenes PI3KR2 and Crk, and the tumor suppressor PLK2. Int J Oncol, 45, 1257-65.

Ma GJ, Gu RM, Zhu M, et al (2013a). Plasma post-operative miR21 expression in the prognosis of gastric cancers. Asian Pac J Cancer Prev, 14, 7551-4.

Ma Y, Wang X, Jin H (2013b). Methylated DNA and microRNA in Body Fluids as Biomarkers for Cancer Detection. Int $\mathrm{J} \mathrm{Mol}$ Sci, 14, 10307-31.

Miao L, Liu K, Xie M, et al (2014). miR-375 inhibits Helicobacter pylori-induced gastric carcinogenesis by blocking JAK2-STAT3 signaling. Cancer Immunol Immunother, 63, 699-711.

$\mathrm{Mu}$ YP, Su XL (2012). Polymorphism in pre-miR-30c contributes to gastric cancer risk in a Chinese population. Med Oncol, 29, 1723-32.

Mu YP, Tang S, Sun WJ, et al (2014). Association of miR193b Down-regulation and miR-196a up-Regulation with Clinicopathological Features and Prognosis in Gastric Cancer. Asian Pac J Cancer Prev, 15, 8893-900.

Naito Y, Yasuno K, Tagawa H, et al (2014). MicroRNA-145 is a potential prognostic factor of scirrhous type gastric cancer. Oncol Rep, 32, 1720-6.

Omura T, Shimada Y, Nagata T, et al (2014). Relapse-associated microRNA in gastric cancer patients after S-1 adjuvant chemotherapy. Oncol Rep, 31, 613-8.

Seok JK, Lee SH, Kim MJ, et al (2014). MicroRNA-382 induced by HIF-1alpha is an angiogenic miR targeting the tumor suppressor phosphatase and tensin homolog. Nucleic Acids Res, 42, 8062-72.

Shen J, Niu W, Zhou M, et al (2014a). MicroRNA-410 Suppresses Migration and Invasion by Targeting MDM2 in Gastric Cancer. PLoS One, 9, 104510.

Shen Q, Yao Q, Sun J, et al (2014b). Downregulation of histone deacetylase 1 by microRNA-520h contributes to the chemotherapeutic effect of doxorubicin. FEBS Lett, 588, 184-91.

Shin JY, Kim YI, Cho SJ, et al (2014). MicroRNA 135a suppresses lymph node metastasis through down-regulation of ROCK1 in early gastric cancer. PLoS One, $\mathbf{9}, 85205$.

Song F, Yang D, Liu B, et al (2014). Integrated microRNA network analyses identify a poor-prognosis subtype of gastric cancer characterized by the miR-200 family. Clin Cancer Res, 20, 878-89.

Song MY, Su HJ, Zhang L, et al (2013). Genetic polymorphisms of miR-146a and miR-27a, H. pylori infection, and risk of gastric lesions in a Chinese population. PLoS One, 8, 61250 .

Sun S, Sun P, Wang C, et al (2014). Downregulation of microRNA-155 accelerates cell growth and invasion by targeting c-myc in human gastric carcinoma cells. Oncol Rep, 32, 951-6.

Sun Y, Zhang K, Fan G, et al (2012). Identification of circulating microRNAs as biomarkers in cancers: what have we got? Clin Chem Lab Med, 50, 2121-6.

Tahara T, Okubo M, Shibata T, et al (2014). Association Between Common Genetic Variants in Pre-MicroRNAs and Prognosis of Advanced Gastric Cancer Treated with Chemotherapy. Anticancer Res, 34, 5199-204.

Tan Z, Jiang H, Wu Y, et al (2014). miR-185 is an independent prognosis factor and suppresses tumor metastasis in gastric cancer. Mol Cell Biochem, 386, 223-31.

Tian SB, Yu JC, Kang WM, et al (2014). [MicroRNA and gastric cancer]. Zhongguo Yi Хие Ке Хие Yиап Хие Bao, 36, 214-7.

Tsai MM, Wang CS, Tsai CY, et al (2014). MicroRNA-196a/-196b promote cell metastasis via negative regulation of radixin in human gastric cancer. Cancer Lett, 351, 222-31.

Tsujiura M, Komatsu S, Ichikawa D, et al (2014). Circulating miR$18 \mathrm{a}$ in plasma contributes to cancer detection and monitoring in patients with gastric cancer. Gastric Cancer.

Tufekci KU, Meuwissen RL, Genc S (2014). The role of microRNAs in biological processes. Methods Mol Biol, 1107, 15-31.

Wang T, Ge G, Ding Y, et al (2014a). MiR-503 regulates cisplatin resistance of human gastric cancer cell lines by targeting IGF1R and BCL2. Chin Med J (Engl), 127, 2357-62.

Wang W, Li F, Zhang Y, et al (2013). Reduced expression of miR-22 in gastric cancer is related to clinicopathologic characteristics or patient prognosis. Diagn Pathol, 8, 102.

Wang Z, Cai Q, Jiang Z, et al (2014b). Prognostic Role of MicroRNA-21 in Gastric Cancer: a Meta-Analysis. Med Sci Monit, 20, 1668-74.

Wu CW, Hsiung CA, Lo SS, et al (2006). Nodal dissection for patients with gastric cancer: a randomised controlled trial. Lancet Oncol, 7, 309-15.

Wu JH, Yao YL, Gu T, et al (2014). MiR-421 regulates apoptosis of BGC-823 gastric cancer cells by targeting caspase-3. Asian Pac J Cancer Prev, 15, 5463-8.

Xia JT, Chen LZ, Jian WH, et al (2014). MicroRNA-362 induces cell proliferation and apoptosis resistance in gastric cancer by activation of NF-kappaB signaling. J Transl Med, 12, 33.

Xu Q, Dong Q, He C, et al (2014a). A new polymorphism biomarker rs629367 associated with increased risk and poor survival of gastric cancer in chinese by up-regulated miRNA-let-7a expression. PLoS One, 9, 95249.

Xu Y, Huang Z, Liu Y (2014b). Reduced miR-125a-5p expression is associated with gastric carcinogenesis through the targeting of E2F3. Mol Med Rep, 10, 2601-8.

Xu Y, Jin J, Liu Y, et al (2014c). Snail-regulated MiR-375 inhibits migration and invasion of gastric cancer cells by targeting JAK2. PLoS One, 9, 99516.

Xu YJ, Fan Y (2014). MiR-215/192 participates in gastric cancer progression. Clin Transl Oncol, 17, 34-40.

Yan W, Wang S, Sun Z, et al (2014). Identification of microRNAs as potential biomarker for gastric cancer by system biological analysis. Biomed Res Int, 2014, 901428 .

Yang M, Shan X, Zhou X, et al (2014a). miR-1271 regulates cisplatin resistance of human gastric cancer cell lines by targeting IGF1R, IRS1, mTOR, and BCL2. Anticancer Agents Med Chem, 14, 884-91.

Yang O, Huang J, Lin S (2014b). Regulatory effects of miRNA on gastric cancer cells. Oncol Lett, 8, 651-6.

Yang Q, Jie Z, Ye S, et al (2014c). Genetic variations in miR-27a gene decrease mature miR-27a level and reduce gastric cancer susceptibility. Oncogene, 33, 193-202.

Yang Q, Zhang C, Huang B, et al (2013). Downregulation of microRNA-206 is a potent prognostic marker for patients with gastric cancer. Eur J Gastroenterol Hepatol, 25, 953-7.

Zhang R, Wang W, Li F, et al (2014a). MicroRNA-106b 25 expressions in tumor tissues and plasma of patients with gastric cancers. Med Oncol, 31, 243.

Zhang XL, Shi HJ, Wang JP, et al (2014b). MicroRNA-218 is upregulated in gastric cancer after cytoreductive surgery and hyperthermic intraperitoneal chemotherapy and increases chemosensitivity to cisplatin. World J Gastroenterol, 20, 11347-55.

Zheng G, Xiong Y, Xu W, et al (2014). A two-microRNA signature as a potential biomarker for early gastric cancer. Oncol Lett, 7, 679-84.

Zheng L, Pu J, Qi T, et al (2013). miRNA-145 targets v-ets erythroblastosis virus E26 oncogene homolog 1 to suppress the invasion, metastasis, and angiogenesis of gastric cancer cells. Mol Cancer Res, 11, 182-93.

Zhou X, Li L, Su J, et al (2014). Decreased miR-204 in H.pyloriassociated gastric cancer promotes cancer cell proliferation and invasion by targeting SOX4. Scientifica (Cairo), 9, 101457.

Zhu ED, Li N, Li BS, et al (2014a). miR-30b, Down-Regulated in Gastric Cancer, Promotes Apoptosis and Suppresses Tumor Growth by Targeting Plasminogen Activator Inhibitor-1. PLoS One, $9,106049$.

Zhu M, Zhang N, He S (2014b). Similarly up-regulated microRNA106a in matched formalin-fixed paraffin-embedded and fresh frozen samples and the dynamic changes during gastric carcinogenesis and development. Pathol Res Pract, 210, 909-15. 